\title{
The Effect of Brand Relationship Quality on Post Purchase Loyalty on Premium Online Learning and Tutoring
}

\author{
Iven Ganesja ${ }^{1, *}$ Daniel Tumpan Aruan ${ }^{2}$
}

\author{
${ }^{1}$ Universitas Indonesia \\ ${ }^{2}$ Universitas Indonesia \\ *Corresponding author.Email: iven.ganesja@yahoo.com
}

\begin{abstract}
In 2018, Indonesia Digital Education and E-Learning Market Outlook issued a report entitled "Rising Trend of Blended to Drive The Future Growth", the shown result was quite surprising because Indonesia was predicted to be the Top 5 Buyers of mobile learning products and services, competing with superpower countries such as China, the United States, together compete with developing countries such as Brazil and India. The total expenditure used to provide digital-based education in Indonesia has also increased in the last five years. The E-learning industry in Indonesia is highly developed. Start-up companies from within and outside the country produce online learning and tutoring with varied learning methods. One of the local online learning and tutoring provider that is having swift moves is Ruang Guru. However, competition between brands is enough to enter a reasonably intense phase. When a company invests in acquiring users, there will be a significant effort for customer retention, especially the usage of premium online learning and tutoring is set as a periodic subscription. This study analyzes the effect of brand relationship elements (satisfaction, commitment, and trust) on brand loyalty after purchasing. Using Partial Least Square as a data processing method. The study results show a significant positive effect of trust, satisfaction, and commitment to one element of brand loyalty, namely repurchase intention. In contrast, no significant positive effect between trust, satisfaction, and commitment with price tolerance will later be discussed in the discussion.
\end{abstract}

Keywords: Brand Relationship Quality, Post Purchase Loyalty, Premium Online Learning and Tutoring.

\section{INTRODUCTION}

Because of the large number of internet users in Indonesia, there is a shift in the behavior of people who are heavily dependent on the internet, one of them in education. E-learning itself is learning arranged to use an electronic or computer system to support the learning process [1]. E-Learning is claimed to have advantages such as saving time, cost, and more effective. ELearning is claimed to have advantages such as saving time, cost, and more effective. Indonesia is a country that has the potential for investors to grow their business in building an online-based learning system due to several factors:

Indonesia's geographical location, as an archipelagic country, uneven development has caused unbalance of conventional courses and training institutions to students' needs, especially in rural areas. According to
Bank Indonesia data, Indonesia's tutoring is $79.9 \%$ in large cities in Indonesia and only $20.1 \%$ in remote areas.

The high cost of conventional tutoring education; according to a Bank Indonesia report Small business financing patterns; commodity tutoring fees services, the average cost of tutoring (conventional tutoring) is at 3.1 million-8.6 million for one school year.

According to reference [2] the number of students in Indonesia in 2017 reached 49,833,002, with the number of educators only $3,133,638$. The comparison between teachers' availability is not proportional to the number of students that is 16 times the total number of teachers. It requires a textbook that is the essential element for implementing optimal teaching and learning activities. Technological developments help distribute materials faster with lower costs. 
In 2018, Indonesia Digital Education and Study issued a report entitled "Rising Trends of Blended to Drive the Future Growth" that said Indonesia was predicted to become the Top 5 Buyers of mobile learning products and services, competing with superpowers like China, America Unions, as well as developing countries such as Brazil and India. The total expenditure used to provide digital-based education in Indonesia has also increased in the last five years. Private educational institutions and the government collaborate to supplement the classes used in learning activities for students with digital-based education facilities. Even now, the government has implemented a computer-based national examination system (UNBK) for ninth and 12th-grade students. This computer-based national examination system has been at- tended by 11,096 junior high / MTs schools, 9652 high schools, 9829 vocational schools level with more than

3.6 million participants. Online tutoring service providers usually sell their services with various learning packages, such as Ruangguru tutoring, which provides packages from elementary to high school with various learning packages. The next question is whether students who decide to use the current online learning service will continue to use it at the next level. To solve this problem, the researcher uses Brand relationship quality to observe Brand Loyalty between online tutoring users. This research discusses both theoretical and business contributions. First, this research is based on a theoretical model developed using PLS-SEM (Partial Least Square), including some modifications.

\subsection{Online learning}

There are many definitions of online learning in the literature that illustrate the diversity of learning practices associated with technology. Reference [3] defined online learning as educational material delivered by using computers. Reference [4] defines online learning as an innovative approach (innovative approach) to convey information to a remote audience, using the web as a medium to deliver information. However, in the process of learning methods using online media must remain focused on learners and the learning process, which must be focused on online learning, among others: the use of the internet to access learning materials, the effectiveness of using online media to interact with content, instructors, and other learners, to get support during the learning process and to build positive learning experiences [5]. The trend of online learning has indeed become a new trend in the modern era like today. Bringing the concept of new learning, which is done without meeting face-to-face with the tutor or instructor, makes online learning an alternative chosen by parents and students to become a learning method. Start-up companies see this phenomenon as business opportunities, plus Indonesian people have made the internet one of their primary needs.

\subsection{Brand relationship}

Reference [6] defines consumer-brand relationships as psychological bonds formed by consumers with brands. Research shows that a brand can be treated as a partner who contributes two directions between consumers and brands [7]. For a dependency relationship to occur between partners, it must be clear: that is, between partners (in this case, the consumerservice provider relationship) must clearly define, partners must collectively influence, define and redefine relations [8]. The premise that consumer action influences the form of relationships and dynamics of relationships are readily accepted. The idea that a brand is not a passive object in a marketing transaction, a brand is no longer something that does not contribute when the transaction occurs but is one of the things that is considered. One way to legitimize brands as partners is to highlight how a brand is animated and personalized. Following the experience approach to brands, reference [9] built a bridge between brand interaction and brand relationship. This approach is based on the proportion of co-creation that brands are formed based on experience [10]. Strong brand relationships are a good basis for building brand-related experience [11], for example, a consumer can participate in an online forum that contains consumers who use the same brand who are members of a brand community [12].

\subsection{Brand relationship quality}

Brand relationship evaluation methods can be sorted into value and indicator methods. The value method focuses on the financial output of the brand relationship. However, the indicator is the "ingredients" of the brand. The difference between the two methods is in the content of research, research thinking, manifestations, and applications [13]. Several research findings in the literature about value methods, such as value assessment systems [14] and customer lifetime values evaluation [15].

\subsection{Servqual}

Reference [16] presented SERVQUAL as a multiitem scale developed to assess service quality defined as the degree or degree of difference between consumer perceptions and expectations of services provided. SERVQUAL requires respondents to answer questions about their expectations and perceptions. Reference [16] outline the idea of service quality into 22 items consisting of 5 contractors: tangibles (physical facilities, equipment, staff performance, etc.), reliability (ability to provide services reliably and accurately), 
responsiveness (willingness to help and responding to customer needs), assurance (the ability of staff to inspire confidence and trust), and empathy (the extent to which service providers care about their customers by providing individual services.

\subsection{Conceptual background and research design}

This study's model was adapted from the model used reference [17] in their research entitled "brand-name relationships and brand loyalty in technology-mediated services", this study aims to improve brand relationship quality amid competition in the Internet Service Provider (ISP). This study modifies the model by adding the SERVQUAL (service quality) component to satisfaction, adapted from [18] in his research entitled The Impact of Inertia and User Satisfaction on The Continuance Intentions to use Mobile Communication Application: A Quality Perspective Mobile Service.

H1: Trusts will have a positive influence on (a). repurchase intention, (b). positive recommendation, and (c) price tolerance.

Figure 1 Show conceptual background and research design.

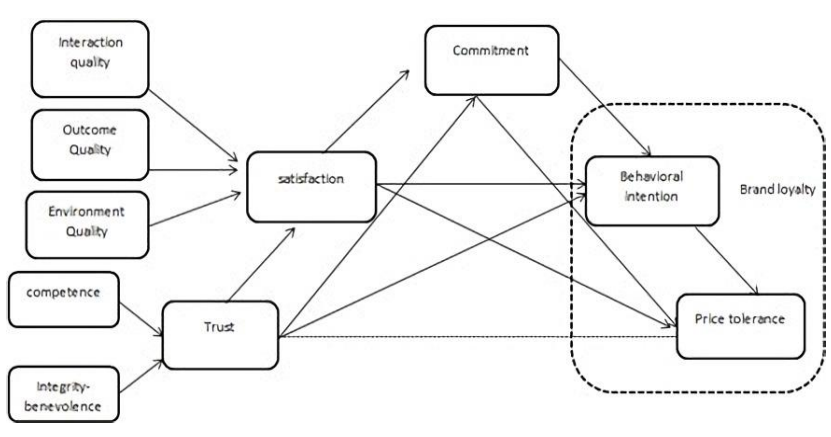

Trust is essential in increasing brand loyalty, especially in high-tech services where the service delivery process has a risk that consumers accept as a significant thing. When customers trust service providers, they will continue to use services and recommend service providers to other potential [19]. Besides, customers who experience trust when interacting with brands feel a reduced risk when using the service. They consider as a benefit then they are willing to pay a higher price [19].

H2: Customer satisfaction will have a positive effect on (a). repurchase intention, (b) positive recommendation.(c) price tolerance

Customer satisfaction is defined as "pleasant customer satisfaction [20]. In other words, satisfaction expresses an adequate response. In other words, satisfaction expresses the effective response of customers who find services that can meet customer needs [21]. Many studies show that satisfaction influences customer loyalty, when customers are delighted, they consider the results of the exchange to be positive and, therefore, willing to make a buyback willing to repurchase [22] to recommend providers to other consumers [22,23], and pay premium prices $[24,22]$.

H3: Affective commitment has a positive influence on (a). repurchase intention, (b) positive recommendation, (c). price tolerance

Many studies have shown that customer repurchase intention, and positive recommendations are considered a consequence of affective commitment [22,25,26]. Research on interpersonal relationships suggests that consumers who have a brand relationship give a higher value to certain brands than competing brands. As a result, they are more willing to invest in certain brands, make sacrifices for the brand, and maintain interaction with the brand.

H4: Trust has a positive influence on (a) satisfaction, (b) effective commitment

Theoretical and empirical evidence shows that trust is an antecedent of brand satisfaction in traditional and electronic services [27-30]. This study's results are based on cognitive consistency, where a person tends to be consistently in a pleasant psychological state. Therefore, it is expected that if the value of satisfaction is greater, the customer will trust the brand more [30], on the other hand, trust is the antecedent of affective commitment [30,31] because fulfilling repeated customer needs can lead to better ties with brands [32]. Finally, trust and brand commitment are the most important drivers of long-term brand relationships.

H5: Satisfaction will have a positive effect on affective commitment.

Recent studies show that with increasing customer trust, the more they commit to the brand $[25,26,33,34]$.

H6: Brand satisfaction and commitment mediates brand trust-brand loyalty relationship

Together, suggest a mediation relationship, where brand trust and brand relationship commitment mediate the impact of brand trust as a manifestation of brand loyalty. In other words, service providers will achieve better brand performance if they can effectively change brand trust into satisfaction and brand commitment to obtain customer loyalty [33].

H7: Service quality (interaction quality, environment quality, outcome quality) has a positive influence on satisfaction. Reference [27] also show that perceptions of service quality are based on consumers' cognitive responses to their evaluation of various aspects of service, including the quality of interactive service 
quality, quality of service facilities, and real aspects from providing services (outcome quality), and therefore crucial in terms of determining user satisfaction concerning certain services.

\section{METHODS}

This study's population was online tutoring users in Indonesia, while the sample of this study was online tutoring users in Indonesia who are in class IX to class XII. This study uses a non-probabilistic method aside, respondents who are under the study sample requirements, i.e., students who use online tutoring, will be taken. Meanwhile, the technique used is convenience sampling. Researchers conduct research by directly taking data in a particular school and distributing questionnaires using the Google form. This study uses the PLS-SEM method. Unlike a covariant-based SEM method that has to use a large sample of hundreds or even thousands of samples, PLS-SEM can be run with a small sample, the small sample size can be used ten times the size of a formative indicator or ten times of the largest formative indicator used to measure latent variable or ten times of the total number of structural. In reference [35] conducted a study using only 20 data, using the PLS method correctly. In this study, researchers used 205 online tutoring user data from class VII to class XII. The scales used to operationalize the proposed model's concepts were adopted from different sources to suit the study. The trust scale that measures its three sub-dimensions of competence (COMP), integrity (INT), and benevolence (BEN) were adopted from [36]. Affective commitment (COM) was measured using the scale proposed by Kwortnik and Han (2011). Finally, the scales proposed by SanchezFranco et al. (2009) were used to measure brand satisfaction and brand loyalty, where the latter comprises three main dimensions: repurchase intentions (RPI), positive recommendations (PREC), and price tolerance (PTOL). All items were measured on a sevenpoint Likert scale ranging from 1 "strongly disagree" to 7 "strongly agree". Exploratory factor analysis and partial least squares path methodology (PLS-PM), an implementation of structural equation modeling (SEM) with Smart PLS 2.0 M3 [37], were employed to examine the validity of our model and test the proposed hypotheses. PLS-PM was preferred over covariancebased SEM because statistical identification with formative models is difficult for covariance-based SEM methodologies, whereas PLS permits the simultaneous testing of hypotheses while enabling both reflective and formative constructs [38].

\section{RESULTS AND DISCUSSION}

\subsection{Hypothesis test}

After processing the data, it can be concluded that trust will have a positive influence and has a significance for repurchase intention, positive, this is proven by a positive original sample value $(0.304)$ and the value of $t$-statistics $(4,454)>$ from $t$ - table 1.65 . This is in line with previous research conducted by Nyffeneger et al., In 2014, where if the customer already had confidence in high-tech service when the service was sent, it would minimize perceived risk, then the customer would not hesitate to recommend to other potential customers, and repurchase. The positive effect of trust on behavioral intention does not apply to the trust and price tolerance relationship, which shows no positive relationship because the original sample value obtained is negative $(-0,136)$. There is no significant effect of trust variables on price tolerance.

$\mathrm{H} 2$ : Customer satisfaction will have a positive effect on (a). repurchase intention, (b) positive recommendation. (c) price tolerance

The results showed that there was a significant positive relationship, this was emphasized by the original sample value obtained from the results of positive data processing, i.e. (0.192), and the value of tstatistics 2.644> of the t-table value (1.65). Also, the value of $p$-values obtained are less than 0.05 . This is in line with the research conducted by Rodolfo VazquezCasielles, where customers who are very satisfied with the services obtained will tend to respond in the form of positive outcomes by recommending potential customers and repurchasing. This is interesting enough to be discussed from the results of data processing. The results show that consumer satisfaction does not have a significant effect on price tolerance. This is emphasized by the results of the t-value static (1.007) smaller than ttable (1.65) and p-value (0.157) greater than 0.05. This was explained by research conducted by Anderson in 1994, where high customer satisfaction does not always make consumers insensitive to prices if the price of services or products rises, it is not necessarily willing to pay a higher price, because consumers will expect more for a service or product if they have to pay a high price.

H3: Affective commitment has a positive influence on (a). repurchase intention, (b) positive recommendation, (c). price tolerance.

Furthermore, the researcher tested hypothesis 3 . From the results of data processing carried out by researchers, the results of affective commitment will give a significant positive effect seen from the positive original sample values, the value t-statistics $(6.774)>t-$ table (1.65) and p-value $(0)<\mathrm{p}$-value table $(0.05)$. This research has also been conducted in a previous study conducted by Sreejesh and Roy in 2015, wherein the 
study concluded that consumers who have formed a commitment to themselves to a particular service or product tend to be willing to in- vest more in the service or product. Nevertheless, in this study, affective commitment and price tolerance are not significant. This is indicated by the t-statistics value of 1.68 greater than the t-table (1.65) and p-value of 0.068 greater than 0.05 .

H4: Trust has a positive influence on (a) satisfaction,(b) affective commitment

The results of the author's data processing show the results of a significant positive relationship between trust variables with satisfaction. This can be seen from the results of the t-statistics value of 6.218 greater than the t-table (1.65), the p-value obtained is greater than 0.05 , the conclusions in this study are corroborated by research that Balaji has carried out in 2015 where customer satisfaction will be greater when consumers believe in certain products or services. The results of the same relationship were also generated by the Trust with Affective commitment. The data processing results showed a positively significant mutual relationship between affective commitment trust variables, which was proven by the value of t-statistics obtained from processing results of 4,577. Table (1.65), a significant and positive relationship between trust and affective commitment has also been proven .577 this value is greater than t-table (1.65). A significant and positive relationship between trust and affective commitment has also been proven from previous studies conducted by [39], where their $10^{\text {th }}$ hypothesis reads, "There is a positive relationship between trust and commitment variables," getting a correlation value of 1,182 at the level of p <0.01 using 204 data.

H5: Test the Relationship of Satisfaction and Effective Commitment

After processing the data using the PLS-SEM method, there is a significant and positive relationship between satisfaction and commitment variables. The value of t-statistics obtained indicates this is greater than the t-table value of 5,567 with a p-value <bof 0.05 . This conclusion is supported by research conducted by [40]. Wherein their 8th hypothesis, which reads "brand satisfaction has a significant relationship with affective commitment," get the value R2 $=0.279$ after testing using ANOVA, this value indicates that there is a relationship mutually influential and positive relationship between satisfaction and affective commitment.

H6. Test Mediation of Satisfaction and Commitment on Trust relationships and Brand Loyalty.

From the table, it can be concluded that the relationship between trust and price tolerance will be significant if it is mediated by satisfaction and commitment together. This result is in line with the research conducted previously by [33], where they examined the role of satisfaction and commitment in Brand Loyalty. They only tried satisfaction as a mediator between trust and brand relationship loyalty but showed insignificant results. They broke the previous theory, which always linked customer satisfaction with customer retention, service usage, and cross-buying [41]. In 2001 [41] added satisfaction and commitment to model 1 (M2) and produced a mutually influential and significant relationship. This step was proved by [33] and proved in their 5-cd hypothesis that if only satisfaction which be-come mediation through trust has no direct influence.

Test the Relationship between Service Quality (Interaction Quality) and satisfaction from the results of data processing. It is found that there are no significant relationships that are positive between Interaction Quality and Satisfaction. This can be deduced from the obtained t-statistics value of 0.034 . This value is smaller than the t-table, which is 1.65 , while the measured pvalue is 0.486 , greater than 0.05 .

Test the Relationship between Service Quality (Environment Quality) and Satisfaction. After the researcher has processed the data, there is an indication that there is no mutually significant re- relationship between the Service Quality (Environment Quality) variable and the satisfaction because the value of $t$ statistics obtained from the research value is 1,254 less than the t-table. Emphasized by the p-value obtained is less than 0.05 .

Test the Relationship between Service Quality (Environment Quality) and Satisfaction. However, positive signs can be found in the Service Quality (Environment Quality) relationship with satisfaction. This is emphasized by the results obtained from data processing, namely the value of t-statistics of 4,014, greater than the t-value. Also, the p-value is smaller than 0.05 .

\section{CONCLUSIONS}

After conducting data processing and analysis that has been described, it can be concluded in the following points:

- Trusts will positively and significantly influence brand loyalty, namely repurchase intention, a positive recommendation but not with a positive recommendation found a non-significant negative effect on the trust relationship test on price tolerance.

- Customer satisfaction will significantly positively affect repurchase intention and positive recommendations but not on price tolerance.

- Affective commitment has a significant positive effect on repurchase intention, positive behavioral 
intention but does not create a significant positive relationship to price tolerance.

- Trust has a positive influence on satisfaction and affective commitment.

- Satisfaction will have a significant positive effect on affective commitment.

- Brand satisfaction and commitment to mediate brand- trust and brand loyalty relationship.

- Interaction Quality does not have a significant positive effect on satisfaction, as well as Environment Quality has no significant positive effect on satisfaction.

- However, Outcome Quality has a positive and significant influence on satisfaction.

\subsection{Managerial implication in hypothesis 1}

It is found that trust has a positive and significant effect on 1 component, brand loyalty, a positive recommendation but not price tolerance. It indicates that consumers in this study are tutoring students, and students, if they have confidence in online tutoring products, they are willing to recommend these products to other potential customers, in this case, are students who have not used online tutoring. However, price tolerance is one issue that has a significant impact on price tolerance. According to [42], price tolerance was closely related to the concept of consumer surplus: the excess of the price a consumer has to pay instead of going without anything. Someone will pay the economy and surplus they get. Therefore, what must be done by online guidance service providers is to conduct marketing research that focuses on "pricing" or pricing. Online learning guidance is sold in the form of "subscription" compared to other products or services, pricing methods used in business with subscription bases, namely Freemium, Consumption, Tiered, and Perpetual Licensing, Promotional strategy. The author suggests using the Promotional Strategy method. A promotional strategy is a strategy used by giving "incentives" to customers. This strategy is a viral strategy among subscription-based businesses. This strategy applies "extra bonuses" to the customer if they subscribe for a more extended period. Compared to giving a "free subscription", this strategy is considered better in shaping customer commitment and restoring customers who are disappointed with the services provided. Online tutoring service providers can make a program where if a more extended period of subscription gets "additional subscription time", for example, a 6-month subscription will get one month free, or extra other features that can be used, for example, "3 sessions of free tutors if subscribing to $\mathrm{X}$ tutoring for 12 months ".

\subsection{Another thing that becomes an issue is that even though consumers feel satisfied and committed, they are susceptible to prices.}

The thing to note here is that online tutors are consumers who are at school age who do not have income. Providers of online tutoring services must build a "Good perception" to the decision making that is the parents of students so that emotional bonding occurs between the brand of online tutoring with parents of students such as holding a program of gathering parents whose children use online tutoring. Alternatively, educating parents from television shows has been done by Ruangguru as one of the online tutoring providers.

\subsection{Outcome quality is an important}

Aspect that shapes satisfaction. This emphasizes that increasing learning outcomes after using online tutoring be- comes one of the formations of satisfaction. Therefore, online tutoring providers should check periodically about budgets.

\section{REFERENCES}

[1] M. Allen, Michael Allen's Guide to E-learning. Canada: John Wiley \& Sons. 2013.

[2] Indonesia Education Statistics in Brief 2017/2018. Indonesian Ministry of Education and Culture (Kemdikbud). 2020. [Online]. Avaible: http://publikasi.data.kemdikbud.go.id/.

[3] S. Carliner, Overview of online learning. Amherst, MA: Human Resource Development Press. 1999.

[4] B.H. Khan, "Web-Based Instruction: What Is It and Why Is It?," In: Khan, B.H., Ed., Web-Based Instruction, Educational Technology Publications, Englewood Cliffs, pp. 5-18, 1997.

[5] M. Ally, Foundations of Educational Theory for Online Learning. 2004.

[6] S. Fournier, "Consumers and their brands: Developing relationship theory in consumer research,” J. Consum. Res., 1998.

[7] S. Fournier S, "The Consumer and the Brand: An Understanding within the Framework of Personal Relationships," Working Paper., Harvard Business School, pp. 97-024, 1996.

[8] R.A. Hinde, Towards Understanding Relationships, London: Academic Press, 1979.

[9] Payne, K. Storbacka, P. Frow, and S. Knox, "Cocreating brands: Diagnosing and designing the relationship experience," J. Bus. Res., 2009. 
[10]C.K. Prahalad and V. Ramaswamy, "Co-creation experiences: The next practice in value creation," J. Interact. Mark., 2004.

[11]C. da Silveira, C. Lages, and C. Simões, "Reconceptualizing brand identity in a dynamic environment,” J. Bus. Res., 2013.

[12]B. Cova, R. Kozinets, and A. Shankar, "Temperance and religiosity in a non-marginal, non-stigmatized brand community: Hope Jensen Schau and Albert M. Muñiz Jr," in Consumer Tribes, 2009.

[13]Z. Zhimin, "Research scope, perspectives and prospects of brand relationship evaluation," Foreign Economics \& Management., vol. 1, no. 1, pp. 34-40, 2005.

[14]FF. Reichheld, The Loyalty Effect, Boston, Massachusetts: Harvard Business School Press, 1996.

[15]R.T. Rust, V.A. Zeithaml, and K.N. Lemon, Driving customer equity: How customer lifetime value is reshaping corporate strategy. New York: Free Press, 2000.

[16] Parasuraman, V.A. Zeithaml, and L.L. Berry, "A conceptual model of service quality and its implications for future research,” J. Mark., 1985.

[17]A.N. Giovanis and P. Athanasopoulou, "Consumer-brand relationships and brand loyalty in technology-mediated services," J. Retail. Consum. Serv., 2018.

[18] W.T. Wang, W.M. Ou, and W.Y. Chen, "The impact of inertia and user satisfaction on the continuance intentions to use mobile communication applications: A mobile service quality perspective,” Int. J. Inf. Manage., 2019.

[19] B. Nyffenegger, H. Krohmer, W.D. Hoyer, and L. Malaer, "Service Brand Relationship Quality: Hot or Cold?,” J. Serv. Res., 2015.

[20] R.L. Oliver, “Whence consumer loyalty?," J. Mark., 1999.

[21] M.K. Brady and J.J. Cronin, "Some new thoughts on conceptualizing perceived service quality: A hierarchical approach,” J. Mark., 2001

[22] R. Vázquez-Casielles, L. Suárez-Álvarez, and A.B. Del Río-Lanza, "Customer satisfaction and switching barriers: Effects on repurchase intentions, positive recommendations, and price tolerance,” J. Appl. Soc. Psychol., 2009.

[23] T.J. Brown, T.E. Barry, P.A. Dacin, and R.F. Gunst, "Spreading the word: Investigating antecedents of consumers' positive word-of-mouth intentions and behaviors in a retailing context," $\mathrm{J}$. Acad. Mark. Sci., 2005.

[24] C. Homburg, N. Koschate, and W.D. Hoyer, "Do satisfied customers really pay more? a study of the relationship between customer satisfaction and willingness to pay," J. Mark., 2005.

[25]P. Thaichon, A. Lobo, C. Prentice, and T.N. Quach, "The development of service quality dimensions for internet service providers: Retaining customers of different usage patterns," J. Retail. Consum. Serv., vol. 21, no. 6, 2014.

[26] S. Sreejesh, and S. Roy, "A new consumer brand relationships framework," Consumer brand relationship., pp. 165-197, 2015.

[27] J.S. Chiou and C. Droge, "Service quality, trust, specific asset investment, and expertise: Direct and indirect effects in a satisfaction-loyalty framework," J. of the Academy of Marketing Science., vol. 34, no. 4, pp. 613-627, 2006.

[28] C.M. Chiu, C.C. Chang, H.L. Cheng, and Y.H. Fang, "Determinants of customer repurchase intention in online shopping," Online Inf. Rev., vol. 33, no. 4, pp. 761-784, 2009.

[29] X. Han, R.J. Kwortnik, and C. Wang, "Service loyalty: An integrative model and examination across service contexts," J. Serv. Res., vol. 11, no. 1, pp. 22-42, 2008.

[30] Sarkar Sengupta, M.S. Balaji, and B.C. Krishnan, "How customers cope with service failure? A study of brand reputation and customer satisfaction,” J. Bus. Res., vol. 68, no. 3, 2015.

[31] G. Fullerton, "The impact of brand commitment on loyalty to retail service brands," Can. J. Adm. Sci., vol. 22, no. 2, pp. 97-110, 2011.

[32] P.A. Vlachos, A. Theotokis, K. Pramatari, and A. Vrechopoulos, "Consumer-retailer emotional attachment: Some antecedents and the moderating role of attachment anxiety," Eur. J. Mark., vol. 44, no. 9,2010

[33]P. Aurier and G. N'Goala, "The differing and mediating roles of trust and relationship commitment in service relationship maintenance and development," J. Acad. Mark. Sci., vol. 38, no. 3, pp. 303-325, 2010.

[34] C. Veloutsou, "Brand evaluation, satisfaction and trust as predictors of brand loyalty: the mediatormoderator effect of brand relationships," J. Consum. Mark., vol. 32, 2015. 
[35] N.P. Chin, Wynne, "Structural Equation Modeling Analysis with Small Samples Using Partial Least Square,” Stat. Strateg. small sample Res., 1999.

[36] D. Harrison McKnight, V. Choudhury, and C. Kacmar, "The impact of initial consumer trust on intentions to transact with a web site: A trust building model," J. Strateg. Inf. Syst., vol. 11, no. 3-4, pp. 297-323, 2002.

[37] C. Ringle, S. Wende, and A. Will, SmartPLS 2.0 (Beta). Hamburg. 2005.

[38] J.M. Becker, K. Klein, and M. Wetzels, "Hierarchical latent variable models in pls-sem: guidelines for using reflective-formative type models," Long Range Plann., vol. 45, no. 5-6, pp. 359-394, 2012.
[39] R.M. Morgan and S.D. Hunt, "The commitmenttrust theory of relationship marketing," J. Mark., 1994.

[40] Erciş, S. Ünal, F.B. Candan, and H. Yıldırım, "The effect of brand satisfaction, trust and brand commitment on loyalty and repurchase intentions," Procedia - Soc. Behav. Sci., vol. 58, pp. 1395 1404, 2012.

[41] Gustafsson, M.D. Johnson, and I. Roos, "The effects of customer satisfaction, relationship commitment dimensions, and triggers on customer retention," J. Mark., vol. 69, no. 4, pp. 210-218, 2005.

[42]E.W. Anderson, "Customer satisfaction and price tolerance,” Mark. Lett., pp. 265-274, 1996. 